\title{
The Length Polymorphism of the Locus psbA-trnH is Idyllic to Detect the Adulterations of Black Pepper with Papaya Seeds and Chili
}

\author{
D.R.R.P. Dissanayake, H.M.P.D. Herath, M.D.M.I.M. Dissanayake, M.D.M. Chamikara, \\ M.M. Jayakody, S.S.C. Amarasekara, K.W.T.R. Kularathna, N.N.H. Karannagoda, \\ M. Ishan, and S.D.S.S. Sooriyapathirana ${ }^{1}$
}

Received: $28^{\text {th }}$ August 2015 / Accepted: $16^{\text {th }}$ November 2015

\begin{abstract}
Black pepper (Piper nigrum L.) is an important spice. The adulteration of black pepper seeds and powder with papaya seeds, green chili and red chili can be seen and limited studies have been conducted to detect these adulterants. The objectives of the present study were to assess the appropriateness of morphometric methods to discriminate papaya seed and chili adulterations in black pepper and to establish a DNA based strategy to detect these adulterations. A necessary adulteration series of seeds and powders were prepared for the analyses along with commercial samples. The appearance of the seed and powder samples were slightly different but not very distinct among the pure and adulterated samples emphasizing the need of a biochemical approach to detect the adulteration. The adulterated and commercial black pepper samples received lower pungency ranks compared to that of pure samples. QIAGEN DNeasy ${ }^{\circledR}$ Plant Mini Kit was successful in extracting PCR amplifiable DNA from any sample without papaya seeds and the modified CTAB method was able to extract required PCR amenable DNA from any sample with papaya seed material. The universal DNA barcoding primer pair, psbA-trnH, was used to amplify the DNA. Black pepper DNA yielded 200 bp band, chili and papaya DNA yielded 450 bp band and DNA from adulterated samples produced both $200 \mathrm{bp}$ and $450 \mathrm{bp}$ bands. Therefore this strategy can be used to detect papaya / chili adulterations in black pepper.
\end{abstract}

Keywords: black pepper adulteration, DNA barcoding, food adulteration, piper nigrum, psbA$\operatorname{trn} H$

\section{INTRODUCTION}

Black pepper, (Piper nigrum L.), "the king of spice", is an essential constituent in global cuisines (Rani et al., 2013) because of its unique pungency due to an alkaloid known as piperine present in the seeds (Srinivasan, 2007). Black pepper seeds are widely used in preparing various curry powders, seasonings, sauces and spice mixtures (Premavalli et al., 2000). Black pepper is also frequently used in folk medical practices especially in treating digestive disorders such as diarrhea and indigestion (Shamkuwar et al.,
2012) and respiratory disorders like cold, fever and asthma (Kim and Lee, 2009). Historically it has been observed that black pepper has noticeable defensive mechanisms against microbes, insects and animals (Rani et al., 2013). According to the latest findings, black pepper also exhibits diverse pharmacological values (Damanhouri and Ahmad, 2014) like antioxidant, anti-inflammatory (Srinivasan, 2005), anti-toxic (Vijayan and Thampuran, 2000), anti-mutagenic (EI-Hamas et al., 2003), 
anti-tumor (Sunila and Kuttan, 2004) and antiapoptotic (Pathak and Khandelwal, 2007) properties.

Because of the food and pharmacological values, black pepper is considered as a major economic crop worldwide. According to the global market reviews in 2014, the world black pepper production was 400,000 metric tons and $5.75 \%$ of the total production was supplied by Sri Lanka which included both black pepper seeds and powder (Nedspice Pepper Crop Report, 2014). In Sri Lanka, total area of black pepper cultivation is about 29,378 ha (Department of Export Agriculture, Sri Lanka, 2015) and produces 23,000 metric tons of seeds annually (Nedspice Pepper Crop Report, 2014). Black pepper seeds and value added products such as powder and whiten seeds are extremely expensive in both local and foreign markets (Department of Export Agriculture, Sri Lanka, 2015; Yogesh and Mokshapathy, 2013). Therefore, black pepper is considered as an important cash crop. Many growers, merchants and stakeholders who are involved in food processing such as drying, grinding, blending and packing are attracted to the black pepper industry in countries where black pepper is predominantly grown.

When a crop is becoming a highly valuable industrial commodity, the natural tendency is to find fraudulent practices to increase the profit margin. There are evidences that, black pepper is adulterated with cheap biological adulterants especially dried papaya (Carica papaya) seeds (Pruthi and Kulkarni, 1969). Dried fruits of Lantana camara and Embelia ribes are the minor adulterants of black pepper reported in India (Singhal et al., 1997). Empty berries, stems and chaff of black pepper are also used as seed adulterants (Ravindran and Kalluparackal, 2001) while colored starch from cheaper sources are reported as adulterants in black pepper powder (Archer, 1987). Moreover, recent reports indicate that black pepper is adulterated with chili (Capsicum annuum and Capsicum spp.) powder (Parvathy et al., 2014). According to Dhanya et al., (2009), papaya seeds are the most common adulterant used in black pepper seed market since both papaya and black pepper seeds have similar appearances. Black pepper powder adulteration with chili powder is also common because both have pungency and chili is cheaper than black pepper (Parvathy et al., 2014). However, these deceitful practices can lower the acceptability of consumers on commercially available black pepper seeds and value added products.

Adulterations can occur at any stage in the manufacturing process and consumers can be exposed to unknown and potentially dangerous ingredients which result in hazardous health issues such as cancers, allergies (Stiborová et al., 2002) and intoxications (Asensio et al., 2008). Therefore, many research studies are being carried out throughout the world to identify the adulterations in food items. Number of methods such as thin layer chromatography (TLC), mass and nuclear magnetic resonance (NMR) spectroscopy methods (Paradkar et al., 2001), super-critical carbon dioxide extraction (Bhattacharjee et al., 2003) and microscopic analysis (Tremlova, 2001) have been employed to detect the food adulterations. However, chromatographic methods are unable to detect adulterations at low concentrations whereas mass and NMR spectroscopic methods require expensive instrumentation thus limiting their suitability in analyzing a large number of samples, especially in developing countries.

DNA based methods, especially DNA barcoding and fingerprinting, are used to detect biological adulterations. DNA evidences overcome the inherent fallacies associated with traditional morphometric measurements of biological entities (Dhanya and Sasikumar, 2010) and can be considered as a $100 \%$ accurate system to authenticate biological commodities. Molecular markers such as 
Randomly Amplified Polymorphic DNA (RAPD), Sequence Characterized Amplified Region (SCAR) (Dhanya and Shasikumar, 2010), microsatellites (Chamikara et al., 2015) and DNA barcoding methods (Parvathy et al., 2014) can be used to detect the presence of DNA from the biological adulterants. However, the employment of molecular methods to detect the biological adulterants is often hindered by the difficulty of extracting good quality DNA from dried biological samples such as papaya seeds. The availability of improved DNA isolation protocols (Nageswara-Rao et al., 2013) and commercial extraction kits can answer this problem (Chamikara et al., 2015).

The DNA barcoding is recently proposed to establish the species identity in which the conserved genomic regions such as $p s b A-$ trn $H, \quad r b c L$ and $m a t K$ are sequenced and utilized as molecular tags to represent the species (Hollingsworth et al., 2011). Other than resolving the taxonomic ambiguities and delimiting species, DNA barcoding could be used to check the species admixtures (Parvathy et al., 2014). The DNA barcoding based authentication of food for the presence of adulterants is a new area of research in Sri Lanka. Few studies have been reported on identification of adulterants in meat (Dunuwille et al., 2013), herbal formulations of Phyllanthus emblica (Mawalagedera et al., 2014) and chili powder (Chamikara et al., 2015). However, no such studies have been conducted to detect the adulterants of black pepper in Sri Lanka. Therefore, the objectives of the present study were to assess the appropriateness of morphometric methods to discriminate papaya seed and chili adulterations in black pepper and to establish a robust DNA fingerprinting strategy to accurately detect the papaya and chili adulterations in black pepper to safeguard the rights of consumers. The $p s b A$-trn $H$ region was used as it provides clear amplification and length polymorphism among the plant species (Pang et al., 2012)

\section{MATERIALS AND METHODS}

\section{Sample Collection}

Leaf and fruit samples of black pepper, papaya and chili were collected. Black pepper samples were collected from the four most commonly grown cultivars in Sri Lanka (Panniyur, Kuchin, UD-21 and MB-12). Papaya samples were collected from three major cultivars grown in Sri Lanka (Red-lady, Sinta and wild type) and chili samples were collected from four predominant chili varieties grown / consumed in Sri Lanka $\{$ Mi-hot, Mi-2, Indian red chili and Kochchi (C. frutescence)\}. The black pepper and papaya seeds and chili pepper pod samples were air dried as in commercial processing of these spices. One portion of each dried sample of black pepper and papaya seeds and chili pods were crushed into a fine powder using a heavyduty commercial grinder. Five commercial samples each from black pepper seeds and powder were purchased from the shops located in Colombo, Kurunegala and Kandy Districts, Sri Lanka. The leaf samples were also obtained from all the varieties of the three species.

\section{Morphometric Analysis}

\section{Detection of papaya seed adulteration in black pepper}

Two pure seed samples containing all four black pepper cultivars and all the three papaya cultivars were prepared. Then, $5 \%, 10 \%, 15 \%$ and $20 \%$ custom made adulterated samples (e.g. 5 seeds of papaya and 95 seeds of black pepper) were prepared using the two pure seed samples. The weight of 100 seeds, density and number of floated seeds were measured in pure, adulterated and commercial samples.

\section{Detection of papaya and chili pepper powder adulteration in black pepper}

Powdered pure samples of black pepper, papaya and chili were obtained (powders from ripen 
red chili and unripen green chili were obtained separately). Then, $5 \%, 10 \%, 15 \%$ and $20 \%$ custom adulterated samples were prepared separately to detect papaya adulteration in black pepper, red chili adulteration in black pepper and green chili adulteration in black pepper (e.g. $5 \mathrm{~g}$ of papaya seeds to $95 \mathrm{~g}$ of black pepper seeds were mixed and crushed). The adulterated mixtures containing all the three adulterants were also prepared. The densities of all those samples were measured.

\section{Organoleptic measurement of pungency}

A total of fifteen participants were requested to rank the pungency of pure black pepper, papaya, chili powder, adulterated mixtures (black pepper powder with papaya powder, chili powder and both), commercial black pepper seeds and powder samples. A glass of carbonated sweet cold drink was provided initially and in between each tasting event to relieve the pungency effect (Chamikara et al., 2015). The scale of 1 to 4 was used for the pungency ranking in which 1 was the least level of pungency and 4 was the highest level.

\section{DNA Fingerprinting}

\section{DNA Isolation}

Genomic DNA was extracted from young leaves and matured dried seeds of black pepper and papaya samples using DNeasy ${ }^{\circledR}$ Plant Mini Kit (Qiagen, Solna, Sweden). The same procedure was applied for extraction of Genomic DNA from young leaves and pods of chili samples.

The isolation of genomic DNA of papaya seeds and powders were also done according to the Cetyl trimethylammonium bromide (CTAB) method explained in Nageswara-Rao et al., (2013) with slight modifications. A total amount of $0.1 \mathrm{~g}$ of papaya seed / powder sample was taken. The sample was then ground with liquid nitrogen in a sterile mortar and pestle. Then, $1.5 \mu \mathrm{l}$ of beta-mercaptoethanol was added to $750 \mu 1$ of pre-warmed extraction buffer (100
$\mathrm{mM}$ Tris-HCl (pH 8.0), 20 mM EDTA, 1.4 $\mathrm{mM} \mathrm{NaCl}, 2 \%$ CTAB, 2\% PVP) just before mixing with the ground tissue. After mixing, it was incubated for 45 mins at $65{ }^{\circ} \mathrm{C}$ in a water bath and was mixed gently in every 10 mins by inverting the tube. After that, an equal volume of phenol : chloroform : isoamyl alcohol (25:24:1) was added and mixed for 10 mins. Then, it was centrifuged for 10 mins at $5000 \mathrm{~g}$ at room temperature. The upper aqueous layer was then transferred into an eppendorf tube and this step was repeated. The re-extraction with Chloroform - isoamyl alcohol (24:1) was also done until a clear aqueous layer was obtained. Genomic DNA was precipitated by adding two volumes of chilled isopropanol and the pellet was washed twice with $250 \mu \mathrm{l}$ of chilled $70 \%$ ethanol. Then, DNA pellet was dissolved in $100 \mu 1$ of TE buffer $[10 \mathrm{mM}$ Tris- $\mathrm{HCl}(\mathrm{pH}$ 8.0), 1 mM EDTA ( $\mathrm{pH}$ 8.0)]. The extracted genomic DNA was treated with $4 \mu \mathrm{l}$ of RNase. Genomic DNA was again re-precipitated with two volumes of chilled isopropanol and $1 / 10^{\text {th }}$ volume of $7.5 \mathrm{M}$ sodium acetate to remove residual polysaccharides from DNA, and the pellet was washed with $100 \mu \mathrm{l}$ of chilled $70 \%$ ethanol before re-suspension in $50 \mu \mathrm{l}$ of TE buffer [10 mM Tris-HCl (pH 8.0), 1 mM EDTA (pH 8.0)]. Finally, the DNA was stored in $-4{ }^{\circ} \mathrm{C}$.

\section{PCR}

The DNA samples extracted from leaves were initially used to optimize the PCR conditions. Then optimized conditions of PCR were employed to amplify the DNA samples extracted from seeds and powders. The PCR amplification was carried out with $p s b A-t r n H$ primer pair (Parvathy et al., 2014) using a thermal cycler (Takara, Otsu Shiga, Japan) with initial denaturation at $94{ }^{\circ} \mathrm{C}$ for $4 \mathrm{~min}$; 35 cycles of denaturation at $94{ }^{\circ} \mathrm{C}$ for $1 \mathrm{~min}$, annealing at $52{ }^{\circ} \mathrm{C}$ for $1 \mathrm{~min}$, extension at 64 ${ }^{\circ} \mathrm{C}$ for $1 \mathrm{~min}$ and final extension at $64{ }^{\circ} \mathrm{C}$ for 8 min (Parvathy et al., 2014). A $20 \mu l$ PCR mixture was prepared containing $1 \times$ Go Taq ${ }^{\circledR}$ Green Master Mix (Promega Corperation, 
Madison, Wisconsin, USA), $0.5 \mu \mathrm{M}$ of each of forward and reverse primers and $1.5 \mu 1$ of DNA template. PCR products were size separated using Ethidium Bromide stained 1.5\% agarose gel electrophoresis.

\section{Data Analysis}

The association between the degree of adulteration and pungency rank was analyzed using the FREQ Procedure in SAS 9.3 (SAS Institute, Cary, NC, USA). The variation of the density of adulterated and commercial samples was analyzed using ANOVA procedure and Least Significant Difference (LSD) of Means in SAS. The DNA fingerprints (i.e. DNA banding profiles of the samples) were compared to identify the specific bands to confirm the adulteration of black pepper powder with papaya and chili.

\section{RESULTS}

\section{Morphometric Analysis}

\section{Seeds}

The external appearance of pure black pepper, pure papaya and custom made adulterated black pepper-papaya seed samples were compared (Figure 01). Adulterated samples were slightly different compared to the pure black pepper seed samples. However, when they were in large bulks it was hard to distinguish papaya seeds from black pepper seeds as both have similar black color.

The weight of 100 seeds was significantly highest in black pepper seeds (6.05 g) and lowest in papaya seeds $(1.59 \mathrm{~g})$. There was no significant weight reduction along the entire series of black pepper adulteration with papaya seeds. Three of the commercial black pepper seed samples were significantly lighter in weight compared to pure black pepper seeds $(P<0.05)$ (Table $01)$. The densities of the pure and commercial black pepper seed samples and adulterated samples were not significantly different among each other. Only the density of papaya seeds was significantly lowest $(0.66)$ compared to other tested samples $(P<0.05)$ (Table 01$)$. The percentage of floating seeds in each pure and commercial black pepper seed samples and adulterated samples were not significantly different among each other and papaya seeds exhibited the significantly highest percentage of floating seeds $(P<0.05)$ (Table 01$)$. The least mean pungency rank was observed in papaya (1.47). The pure and commercial black pepper samples and black pepper-papaya adulteration mixtures did not show very different pungency ranks (Table 01).

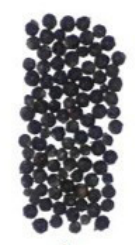

A

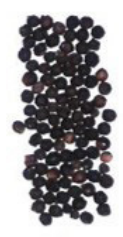

$\mathbf{B}_{1}$

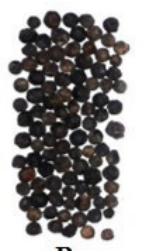

$\mathrm{B}_{2}$

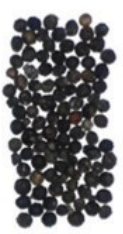

B $_{3}$

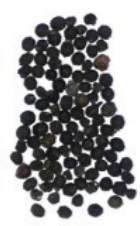

B $_{4}$

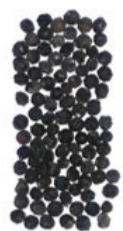

B $_{5}$

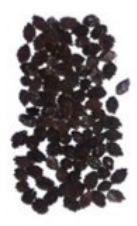

C

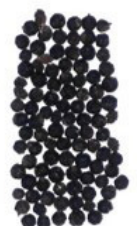

D

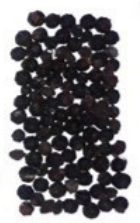

E

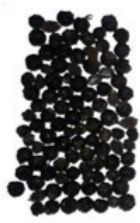

F

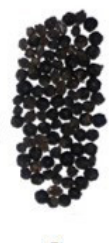

G

Figure 01: Appearance of adulterated and pure seed samples of black pepper and papaya. A: pure black pepper seeds; $B_{1}, B_{2}, B_{3}, B_{4}$ and $B_{5}$ : black pepper seed samples collected from the markets; $C$ : pure papaya seeds; $D$ - $\mathbf{G}$ different levels of adulterations using papaya seeds; D: 5\% adulteration, E: 10\%, F: 15\%, G: $20 \%$ 
Table 01: Comparison of mass and pungency rank of the samples comprised of pure seeds, commercially available seeds and custom made adulterations

\begin{tabular}{lccccc}
\hline \multicolumn{2}{c}{ Sample / Adulteration } & Weight of 100 & Density & $\begin{array}{c}\text { \% floating } \\
\text { seeds }\end{array}$ & $\begin{array}{c}\text { Mean pungency } \\
\text { rank }\end{array}$ \\
\hline \multirow{2}{*}{ Pure seed samples } & Black pepper & $6.05^{\mathrm{a}}$ & $1.01^{\mathrm{a}}$ & $18.50^{\mathrm{b}}$ & 2.27 \\
& Papaya & $1.59^{\mathrm{c}}$ & $0.66^{\mathrm{b}}$ & $84.00^{\mathrm{a}}$ & 1.47 \\
\hline \multirow{3}{*}{ Commercial samples } & 1 & $4.50^{\mathrm{a}}$ & $0.95^{\mathrm{a}}$ & $6.25^{\mathrm{b}}$ & 2.47 \\
& 2 & $4.51^{\mathrm{a}}$ & $0.86^{\mathrm{a}}$ & $12.75^{\mathrm{b}}$ & 2.33 \\
& 3 & $4.04^{\mathrm{b}}$ & $0.91^{\mathrm{a}}$ & $16.50^{\mathrm{b}}$ & 2.60 \\
\hline \multirow{3}{*}{ Black pepper-papaya seed } & 4 & $3.26^{\mathrm{b}}$ & $0.91^{\mathrm{a}}$ & $17.75^{\mathrm{b}}$ & 2.53 \\
adulterated mixtures (\% papaya & 5 & $3.77^{\mathrm{b}}$ & $0.84^{\mathrm{a}}$ & $18.25^{\mathrm{b}}$ & 2.73 \\
seeds) & $5 \%$ & $6.37^{\mathrm{a}}$ & $0.98^{\mathrm{a}}$ & $18.25^{\mathrm{b}}$ & 2.27 \\
& $10 \%$ & $5.84^{\mathrm{a}}$ & $0.97^{\mathrm{a}}$ & $20.00^{\mathrm{b}}$ & 2.13 \\
\hline
\end{tabular}

Means denoted by same letters within each column are significantly different at $P<0.05$

\section{Powders}

The external appearances of pure and adulterated powder samples of black pepper, papaya seeds, dried green chili and red chili were compared (Figure 02). Adulterated samples were slightly different compared to the pure black pepper powder samples. However, when they were in large bulks and presented without any comparison to a standard, it was hard to differentiate pure black pepper powder from the adulterated powders.

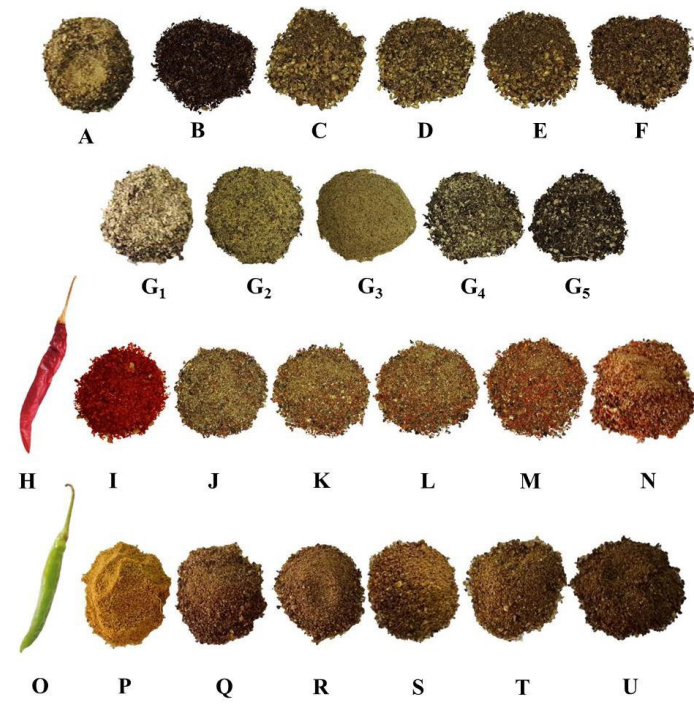

Figure 02: Appearance of black pepper powder samples due to the effect of adulterations with papaya seed powder and chili powder. A: powdered pure black pepper seeds; B: powdered pure papaya seeds; $\mathrm{C}-\mathrm{F}$ represent different levels of adulterations using papaya seeds (in powder form); $\mathrm{C}: 5 \%$ adulteration, D: 10\%, E: 15\%, F: 20\%; G1-G5 represent commercial black pepper powder samples collected from the markets; $\mathrm{H}$ : red chili pod; I: powdered red chili (pure); J-M represent different levels of adulterations using red chili powder; J: 5\% adulteration, K: $10 \%, \mathrm{~L}: 15 \%, \mathrm{M}: 20 \%$; N: black pepper powder adulterated with both papaya seed powder and red chili powder; O: green chili pod; P: powdered dried green chili (pure); Q-T represent different levels of adulterations using green chili powder; $Q: 5 \%$ adulteration, R: 10\%, S: 15\%, T: 20\%; U: black pepper powder adulterated with both papaya seed powder and green chili powder. 
When black pepper powder is considered, adulterations could come from the powdered papaya seeds, dried green chili, red chili and any combinations. The significantly highest density values were observed for four of the commercial black pepper powder samples; custom made adulterated powders of black pepper and papaya; black pepper - dried green chili; and black pepper - dried green chili - papaya seeds (0.37 to 0.46). Custom made pure black pepper powder and one of the commercial black pepper powder samples had the significantly lower densities (0.34 and 0.28 respectively). The custom made pure dried papaya, green chili and red chili powders exhibited the significantly least densities $(0.21,0.19$ and 0.19 respectively) $(P<0.05)$ (Table 02).

The mean pungency rank was highest in custom made black pepper powder, green chili powder and red chili powder (3.40, 3.60 and 3.53 respectively). The commercial black pepper powder samples and adulterated mixtures of any combinations exhibited similar pungency ranks and in general, their pungency ranks were lower than that of pure black pepper, dried green chili and red chili powders $(0.21,0.19$ and 0.19 respectively) (Table 02 ).

Table 02: Morphometric measurements of pure powder samples, commercial powder samples and custom made adulterated powder samples

\begin{tabular}{|c|c|c|c|}
\hline \multicolumn{2}{|c|}{ Sample } & Density & Mean pungency rank \\
\hline \multirow{4}{*}{ Pure samples } & Black pepper & $0.34^{b}$ & 3.40 \\
\hline & Papaya & $0.21^{\mathrm{c}}$ & 1.17 \\
\hline & Green chili & $0.19^{\mathrm{c}}$ & 3.60 \\
\hline & Red chili & $0.19^{c}$ & 3.53 \\
\hline \multirow{5}{*}{ Commercial } & 1 & $0.44^{\mathrm{a}}$ & 2.00 \\
\hline & 2 & $0.41^{\mathrm{a}}$ & 2.02 \\
\hline & 3 & $0.41^{\mathrm{a}}$ & 1.85 \\
\hline & 4 & $0.28^{\mathrm{b}}$ & 1.76 \\
\hline & 5 & $0.46^{\mathrm{a}}$ & 1.62 \\
\hline \multicolumn{4}{|c|}{ Black pepper - papaya adulteration } \\
\hline \multirow{4}{*}{$\begin{array}{l}\text { Black pepper - papaya } \\
\text { mixture }\end{array}$} & $5 \%$ & $0.41^{\mathrm{a}}$ & 2.00 \\
\hline & $10 \%$ & $0.42^{\mathrm{a}}$ & 1.67 \\
\hline & $15 \%$ & $0.37^{\mathrm{a}}$ & 2.00 \\
\hline & $20 \%$ & $0.43^{\mathrm{a}}$ & 2.13 \\
\hline \multicolumn{4}{|c|}{ Black pepper - green chili adulteration } \\
\hline \multirow{4}{*}{$\begin{array}{l}\text { Black pepper - green } \\
\text { chili mixture }\end{array}$} & $5 \%$ & $0.46^{\mathrm{a}}$ & 2.13 \\
\hline & $10 \%$ & $0.46^{\mathrm{a}}$ & 2.00 \\
\hline & $15 \%$ & $0.46^{\mathrm{a}}$ & 2.20 \\
\hline & $20 \%$ & $0.46^{\mathrm{a}}$ & 2.13 \\
\hline \multicolumn{2}{|c|}{ Black pepper - green chili - papaya mixture } & $0.46^{\mathrm{a}}$ & 2.07 \\
\hline \multicolumn{4}{|c|}{ Black pepper - red chili adulteration } \\
\hline \multirow{4}{*}{$\begin{array}{l}\text { Black pepper - red } \\
\text { chili mixture }\end{array}$} & $5 \%$ & $0.29^{\mathrm{b}}$ & 1.87 \\
\hline & $10 \%$ & $0.24^{\mathrm{b}}$ & 1.93 \\
\hline & $15 \%$ & $0.27^{\mathrm{b}}$ & 2.13 \\
\hline & $20 \%$ & $0.26^{\mathrm{b}}$ & 2.53 \\
\hline \multicolumn{2}{|c|}{ Black pepper - red chili - papaya mixture } & $0.28^{\mathrm{b}}$ & 2.33 \\
\hline
\end{tabular}

Means denoted by same letters within each column are significantly different at $P<0.05$ 


\section{Effects of adulterations on pungency}

The adulteration of black pepper with papaya seeds, dried green chili and red chili did not cause any pungency reduction within the ratios studied. The chi square values were not significant for the association between adulterations (5\% to $20 \%$ ) and the pungency ranks given by the taste panelists. However, when the adulterants were considered separately in comparison to black pepper either in seed or powder forms, the association between the components and the pungency rank was extremely significant $(P<$ 0.0001) (Table 03) indicating red chili and green chili are more pungent than that of black pepper and papaya seeds are least pungent (Table 02). The Cramer's V Coefficients for the significant associations were in the range of 0.47 to 0.52 implying that pungency rank (i.e. individual perception) has no perfect linear relationship with the type of plant material.

\section{DNA Isolation}

The QIAGEN DNeasy ${ }^{\circledR}$ Plant Mini Kit was successfully used to extract DNA from all the samples. According to the different intensities of the bands obtained for genomic DNA in agarose gel, higher concentrations of DNA were observed in samples extracted from seeds than that of leaves (Figure 03A). However, DNA samples extracted from any sample containing papaya seeds did not amplify when subjected to PCR, hence modified CTAB method was employed to extract DNA from the samples containing papaya seeds and clear bands were observed when subjected to agarose gel electrophoresis (Figure 03B).

\section{DNA Marker Polymorphism}

The primer pair psbA-trnH yielded approximately $450 \mathrm{bp}$ sized band for the DNA samples obtained from chili and papaya leaves and approximately $200 \mathrm{bp}$ sized band was obtained for the DNA sample from black pepper. When DNA extracted from pure seeds / adulterated samples, the same $200 \mathrm{bp}$ sized band was observed for black pepper and both 200 bp and $450 \mathrm{bp}$ sized bands were observed for black pepper and chili adulterations. However, no amplification was observed for any DNA sample came from a source containing papaya seeds purely or partially when QIAGEN DNeasy ${ }^{\mathbb{R}}$ Plant Mini Kit was used (Figure 04A).

Table 03: The association analysis for the effect of adulteration on the degree of pungency

\begin{tabular}{llcc}
\hline \multicolumn{1}{c}{ Nature of sample } & \multicolumn{1}{c}{ Components } & $\begin{array}{c}\text { Chi Square value } \\
\text { and probability }\end{array}$ & $\begin{array}{c}\text { Cramer's V } \\
\text { coefficient }^{\mathrm{c}}\end{array}$ \\
\hline Adulterated seeds & Black pepper and papaya & $5.54,0.7847$ & 0.18 \\
& Black pepper and papaya seed material & $10.91,0.2821$ & 0.25 \\
& Black pepper and dried green chili & $12.60,0.1811$ & 0.26 \\
Adulterated powder & Black pepper and red chili & $11.18,0.2635$ & 0.25 \\
& Black pepper, dried green chili / red chili, and papaya & $2.45,0.4836$ \\
Pure seeds and pure powders & Black pepper, dried green chili, red chili and papaya & $73.53,<0.0001$ \\
$\begin{array}{l}\text { Pure seeds and pure powders without } \\
\text { papaya }\end{array}$ & Black pepper, dried green chili and red chili & $39.62,<0.0001$ \\
\hline
\end{tabular}

${ }^{\text {a }}$ Chi square value calculated for the association between samples and the pungency rank given for each sample by the taste panel.

${ }^{\mathrm{b}}$ Probability value associated with the chi square value (Calculated by PROC FREQ in SAS). Note that only the values shown in bold case are indicating significant associations $(P<0.0001)$.

${ }^{\mathrm{c}}$ Cramer's V coefficient expresses the strength of association between the sample and the pungency rank. It ranges from 0 to 1; 0 : weakest association and 1: strongest association. 


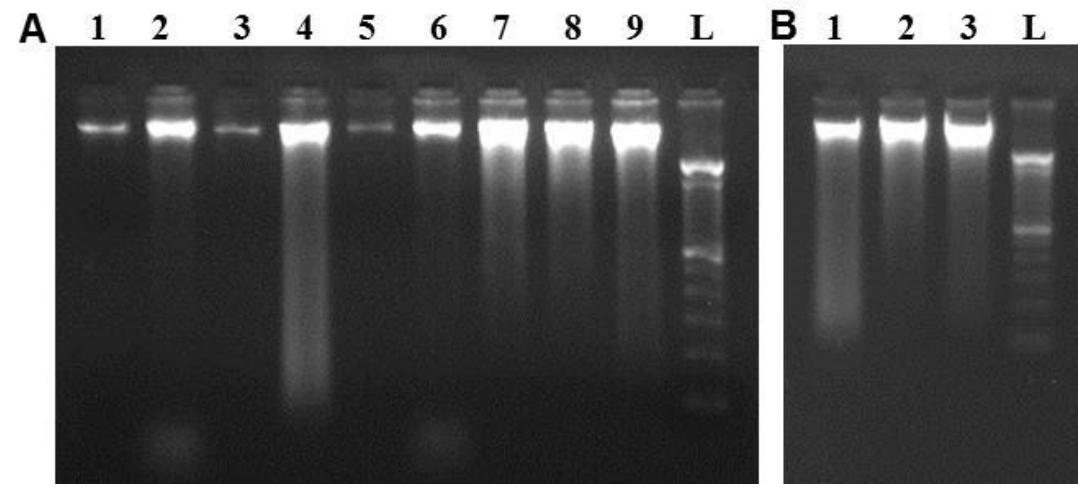

Figure 03: Visualization of the extracted genomic DNA samples. A: Genomic DNA samples extracted from QIAGEN DNeasy ${ }^{\circledR}$ Plant Mini Kit were electrophoresed on $1.5 \%$ agarose gel. DNA samples are from; 1: black pepper leaves, 2: black pepper seeds, 3: chili leaves, 4: chili pods, 5: papaya leaves, 6: papaya seeds, 7: black pepper and chili adulterated mixture, 8: black pepper and papaya adulterated seed mixture, 9: black pepper, papaya seed and chili mixture 10: molecular marker (100 bp ladder). B: Genomic DNA samples extracted using modified CTAB method was electrophoresed on 1.5\% agarose gel. DNA samples are from 1: papaya seeds, 2: black pepper and papaya seed adulterated mixture, 3: black pepper, papaya seed and chili adulterated mixture, 4: molecular marker (100 bp ladder).

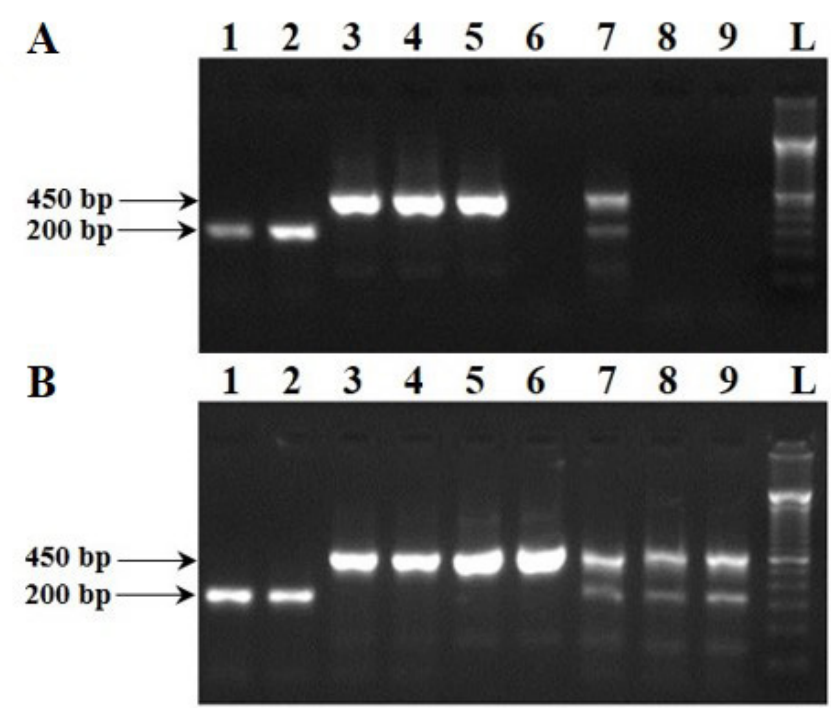

Figure 04: psbA-trnH PCR products for black pepper, chili and papaya DNA obtained from pure and adulterated powder samples. A: PCR products of genomic DNA extracted using QIAGEN DNeasy ${ }^{\circledR}$ Plant Mini Kit from the samples; 1: black pepper leaves, 2: black pepper seeds, 3: chili leaves, 4:- chili powder, 5: papaya leaves, 6: papaya seeds, 7: black pepper and chili powder adulterated mixture, 8: black pepper and papaya seed adulterated mixture, 9: black pepper, papaya seed and chili powder adulterated mixture, L: molecular marker (100 bp ladder). B: PCR products of genomic DNA extracted using QIAGEN DNeasy ${ }^{\circledR}$ Plant Mini Kit from the samples; 1: black pepper leaves, 2: black pepper seeds, 3: chili leaves, 4: chili powder, 5: papaya leaves and 7: black pepper and chili powder adulterate mixture and PCR products of genomic DNA extracted using modified CTAB method from the samples; 6: papaya seeds, 8: black pepper and papaya seed adulterated mixture, 9: black pepper, papaya seed and chili adulterated mixture and L: molecular marker (100 bp ladder).

When DNA samples extracted from a source expected amplifications were obtained. The 200 containing papaya seeds using modified CTAB bp sized band was given for black pepper DNA, method subjected to $p s b A-t r n H$ primed PCR, 450 bp sized band was given for papaya or chili 
DNA and both 200 bp and 450 bp bands were given for the adulterated samples containing black pepper and papaya seeds and / or chili (Figure 04B).

\section{DISCUSSION}

Food fraud and adulterations are serious misconducts in modern world (Dhanya and Sasikumar, 2010). Urgent and robust methods are required to rapidly detect the food adulterations to take legal actions against the responsible parties. In the present study, the adulteration of black pepper seeds and powder with papaya seeds and dried green and red chili was studied. Seeds are a waste material in papaya fruit industry and when these seeds are added to black pepper seeds, counterfeit black pepper seed / powder sellers can increase their profits significantly. Red chili and dried green chili are less expensive (dried chili has one third of the price of black pepper seeds) compared to black pepper and because of their pungency, sellers or producers of black pepper powder might think that some sort of adulteration would not reduce the pungency of black pepper which is also supported by the present study. Expired red and green chili can also be significant adulterants when dried and powdered with black pepper. The morphometric measurements such as weight of 100 seeds, density and pungency rank cannot be clearly used to discriminate the adulterated black pepper seed samples from the pure samples. Non-significant associations between the pungency rank and the adulterations of black pepper up to $20 \%$ with papaya, dried green chili and red chili, clearly provide a room for the adulterations without getting caught (Table 03). The dried green chili and red chili are hotter than black pepper and when adulterated up to about $20 \%$ no extra pungency was felt by the taste panel as estimated in non-significant chi square values and very low Cramer's V Coefficients (Table 03). In summary smaller amounts of papaya seeds, dried green chili or red chili in black pepper would definitely go unnoticed by the customers. External appearance of the pure and adulterated samples of seeds and powder have some differences, but when present alone in the market without side by side authenticated samples, it would be hard for the consumers or food police to detect the adulterations. This clearly highlights the importance of establishing biochemical and molecular methods to detect the adulterations of papaya seeds and chili in black pepper seeds and powder.

Determination of the benzyl glucosinolate content (Curl and Fenwick, 1983) and employment of High-Performance Liquid Chromatography (HPLC) (Parvathy et al., 2014) have been reported as the biochemical methods to detect the papaya seed and chili adulterants respectively in black pepper powder. A SCAR marker was developed by Dhanya et al., (2009) to detect the papaya seed adulterations in black pepper. However, DNA barcoding using the universal primer pairs is the most robust and accurate approach to establish the species identity (Chase et al., 2005; Hollingsworth et al., 2011) and must be preferred over the DNA marker based fingerprinting. The $p s b A$-trnH primer pair based PCR is an ideal molecular platform to detect the papaya seed and / or red / dried green chili adulterations in black pepper. DNA barcoding is generally done with DNA sequencing of sequence tagged sites amplified by barcoding primer pairs (Hollingsworth et al., 2011). However, it could be often expensive and sometimes repeated sequencing is required to validate the DNA barcodes due to technical errors further increasing the cost of DNA sequencing. But fortunately $p s b A$-trn $H$ PCR produces a band for black pepper which is much shorter than that of papaya or chili making an easy separation in less expensive and conducive agarose gel electrophoresis. If two bands are present (200 bp and $450 \mathrm{bp}$ ), definite adulteration is implied and only $200 \mathrm{bp}$ sized band must be present in pure black pepper samples. The band sizes obtained in the present study are in accordance with GenBank entries (papaya gi|764013321, 
chili gi|478430718, black pepper gi|449714585) (www.ncbi.nlm.nih.gov). Moreover, the psbA$\operatorname{trn} H$ was explained as an effective primer pair for easy PCR amplification for DNA barcoding (Kress and Erickson, 2007) and successfully employed by Parvathy et al., (2014) to detect the adulterations of black pepper with chili in India. However, in Sri Lanka, the major adulterant to black pepper is dried papaya seeds and no reported study has paid attention to device a molecular strategy to solve this problem.

The QIAGEN DNeasy ${ }^{\circledR}$ Plant Mini Kit could be used to extract DNA from the samples. However, DNA extracted from any sample which contained papaya seeds (completely or partially) was not amenable to PCR amplification. A modified CTAB method was required to remove the nuisance inhibitors in the DNA extracted from papaya seeds. Nageswara-Rao et al., (2013) argued that these inhibitors could be the contaminants of proteins, polysaccharides and polyphenols present in papaya seeds. It would be an interesting discovery if these inhibitors can be precisely characterized from the papaya seeds. In the present study, custom made black pepper, chili and papaya seeds samples were prepared by pooling all the predominant cultivars / varieties of each crop species in the country. This step is pretty much important to apply the results of the present study to assess the market samples coming from every corner of the country. The lower pungency rank recorded for the commercial samples strongly suggest the possibility of adulterations and as a next step of the present study, the commercially available black pepper samples can be tested after getting the consent from the government.

\section{CONCLUSIONS}

Morphometric parameters such as weight of 100 seeds, density, external appearance and degree of differences in pungency cannot be used to detect the adulteration of black pepper seeds / powder with papaya seeds, red chili and green chili. DNA barcoding primer pair $p s b A-$ trnH can be successfully employed to detect these adulterations. When any black pepper seed / powder sample is supposed to contain papaya seeds, modified CTAB procedure should be used to extract DNA and if not QIAGEN DNeasy $^{\circledR}$ Plant Mini Kit can be used for the DNA isolation.

\section{ACKNOWLEDGEMENT}

Central Research Station, Department of Export Agriculture, Matale, Sri Lanka.

\section{REFERENCES}

Archer, A.W. (1987). The adulteration of white pepper with rice starch, Journal of the Association of Public Analysts. 25: pp. 43-46.

Asensio, L., Gonzalez, I., Garcya, T. and Martyn, R. (2008). Determination of food authenticity by enzyme-linked immunosorbent assay (ELISA), Food Control. 19: pp. 1-8. http://dx.doi. org/10.1016/j.foodcont.2007.02.010

Bhattacharjee, P., Singhal, R.S. and Gholap, A.S. (2003). Supercritical carbon dioxide extraction for identification of adulteration of black pepper with papaya seeds, Journal of the Science of Food and Agriculture. 83: pp. 783-786.

Chamikara, M.D.M., Ishan, M., Dissanayake, D.R.R.P. and Sooriyapathirana, S.D.S.S. (2015). Morphometric and DNA fingerprinting strategies for the detection of rice flour adulteration in chili powder, Rajarata University Journal. 3: pp 25-36. 
Chase, M.W., Salamin, N., Wilkinson, M., Dunwell, J.M., Kesanakurthi, R.P., Haidar, N. and Savolainen, V. (2005). Land plants and DNA barcodes: short-term and long-term goals, Philosophical Transactions of the Royal Society B. 360: pp. 1889-1895. http://dx.doi. org/10.1098/rstb.2005.1720 PMid:16214746 PMCid:PMC1609218

Curl CL, and Fenwick GR (1983) On the determination of papaya seed adulteration of black pepper, Food Chemistry 12 (4): pp. 241-247. http://dx.doi.org/10.1016/0308-8146(83)90012-2

Damanhouri, Z.A. and Ahmad, A. (2014). A Review on Therapeutic Potential of Piper nigrum L. (Black Pepper): The King of Spices, Medicinal \& Aromatic Plants. 3: pp. 1-6.

Department of Export Agriculture (DEA) (2015) http://www.exportagridept.gov.lk/ 15.08.2015. http://dx.doi.org/10.4172/2167-0412.1000161

Dhanya, K. and Sasikumar, B. (2010). Molecular marker based adulteration detection in traded food and agricultural commodities of plant origin with special reference to spices, Current Trends in Biotechnology and Pharmacy. 4: pp. 454-489. http://dx.doi. org/10.1080/08905430902873007

Dhanya, K., Syamkumar, S. and Sasikumar, B. (2009). Development and application of SCAR marker for the detection of papaya seed adulteration in traded black pepper powder, Food Biotechnology. 23: pp. 97-106.

Dunuwille, S.W.M.B., Premachandra, T.N., Rajapaksha, P., Rajapakse, S., Sooriyapathirana, S.D.S.S., Jayawardane, B.C., Himali, S.M.C. and Kodithuwakku, S. (2013). Development of a PCR based genotyping procedure to identify the adulterations to beef in Sri Lankan meat market, Proceedings of the Research Symposium of Uva Wellassa University, Sri Lanka. pp. 7-9.

El-Hamss, R., Idaomar, M., Alonso-Moraga, A. and Munoz-Serra, A. (2003). Antimutagenic properties of bell and black peppers, Food and Chemical Toxicology. 41: pp. 41-47. http:// dx.doi.org/10.1016/S0278-6915(02)00216-8

Hollingsworth, P.M., Graham, S.W. and Little, D.P. (2011). Choosing and using a plant DNA barcode, PLoS ONE 6: e19254. http://dx.doi.org/10.1371/journal.pone.0019254

Kim, S.H. and Lee, Y.C. (2009). Piperine inhibits eosinophil infiltration and airway hyper responsiveness by suppressing $\mathrm{T}$ cell activity and $\mathrm{Th} 2$ cytokine production in the ovalbumininduced asthma model, Journal of Pharmacology and Pharmacotherapeutics. 61: pp. 353359. http://dx.doi.org/10.1211/jpp.61.03.0010

Kress, W.J. and Erickson, D.L. (2007). A two-locus global DNA barcode for land plants: The coding rbcL gene complements the non-coding trnH-psbA spacer region, PLoS ONE. 2: pp. 1-10. http://dx.doi.org/10.1371/journal.pone.0000508 PMid:17551588 PMCid:PMC1876818

Mawalagedera, S.M.U.P., Janaththani, P., Dunuwille, S.W.M.B., Perera, G.A.D. and Sooriyapathirana, S.D.S.S. (2014). DNA based authentication of the presence of Phylanthus emblica (v. nelli) in crude drugs and multicomponent herbal formulations in Sri Lanka, Proceedings of the Young Scientists Forum (YSF) symposium, National Science and Technology Commission (NASTEC) Sri Lanka. 3: pp. 105. 
Nageswara-Rao, M., Kwit, C., Agarwal, S., Patton, M.T., Skeen, J.A., Yuan, J.S., Manshardt, R.M. and Stewart-Jr, C.N. (2013). Sensitivity of a real-time PCR method for the detection of transgenes in a mixture of transgenic and non-transgenic seeds of papaya (Carica papaya L.), BMC Biotechnology. 13: pp. 1-11. http://dx.doi.org/10.1186/1472-6750-13-69 PMid:24004548 PMCid:PMC3766677

Nedspice Pepper Crop Report (2014) www.nedspice.com/ upload/docs/Nedspice_Pepper_Crop_ Report_2014_ESA.pdf. 11.08.2015.

Pang, X., Liu, C., Shi, L., Liu, R., Liang, D., Li, H., Cherny, S.S. and Chen, S. (2012). Utility of the trnH-psbA intergenic spacer region and its combinations as plant DNA barcodes: a meta-analysis, PLoS ONE. 7: pp. 1-9. http://dx.doi.org/10.1371/journal.pone.0048833 PMid:23155412 PMCid:PMC3498263

Paradkar, M.M., Singhal, R.S. and Kulkarni, P.R. (2001). A new TLC method to detect the presence of ground papaya seed in ground black pepper, Journal of the Science of Food and Agriculture. 81: pp. 1322-1325. http://dx.doi.org/10.1002/jsfa.946

Parvathy, V.A., Swetha, V.P., Sheeja, T.E., Leela, N.K., Chempakam, B. and Sasikumar, B. (2014). DNA barcoding to detect chilli adulteration in traded black pepper powder, Food Biotechnology. 28: pp. 25-40. http://dx.doi.org/10.1080/08905436.2013.870078

Pathak, N. and Khandlewal, S. (2007). Role of oxidative stress and apoptosis in cadmium induced thymicatropy and splenomegaly in mice, Toxicology Letters. 169: pp. 95. http://dx.doi. org/10.1016/j.toxlet.2006.12.009 PMid:17267144

Premavalli, K.S., Majumdar, T.K. and Malini, S. (2000). Quality evaluation of traditional products Garam masala and puliyodara mix masala, Indian Spices. 57: pp. 10-13.

Pruthi, J.S. and Kulkarni, B.M. (1969). A simple technique for the rapid and easy detection of papaya seeds in black pepper berries, Indian Food Packer. 2: pp. 51-52.

Rani, S.K.S., Saxena, N. and Udaysree (2013). Antimicrobial Activity of Black Pepper (Piper nigrum L.), Global Journal of Pharmacology. 7(1): pp. 87-90.

Ravindran, P.N. and Kalluparackal, J.A. (2001). Black pepper. In: Handbook of herb and spices (Peter, K.V. Ed.), CRC press, Boca Raton. pp. 62-95.

Shamkuwar, P.B., Shahi, S.R. and Jadhav, S.T. (2012). Evaluation of antidiarrheal effect of Black pepper (Piper nigrum L.), Asian Journal of Plant Science and Research. 2: pp. 48-53.

Singhal, R.S., Kulkarni, P.R. and Rege, D.V. (1997). Handbook of indices of food quality and authenticity, Woodhead Publishing Ltd, Cambridge, UK. pp. 561. http://dx.doi. org/10.1533/9781855736474

Srinivasan, K. (2005). Spices as influencers of body metabolism: an overview of three decades of research, Food Research International. 38: pp. 77-86. http://dx.doi.org/10.1016/j. foodres.2004.09.001 
Srinivasan, K. (2007). Black Pepper and its Pungent Principle-Piperine: A Review of Diverse Physiological Effects, Critical Reviews in Food Science and Nutrition. 47: pp. 735-748. http://dx.doi.org/10.1080/10408390601062054 PMid:17987447

Stiborová, M., Martinek, V., Rýdlová, H., Hodek, P. and Frei, E. (2002). Sudan I Is a Potential Carcinogen for Humans. Evidence for Its Metabolic Activation and Detoxication by Human Recombinant Cytochrome P450 1A1 and Liver Microsomes, Cancer Research. 62: pp. 5678-5684.

Sunila, E.S. and Kuttan, G. (2004). Immuno modulatory and antitumor activity of Piper longum Linn. and Piperine, Journal of Ethnopharmacology. 90: pp. 339-346. http://dx.doi. org/10.1016/j.jep.2003.10.016 PMid:15013199

Tremlova, B. (2001). Evidence of spice black pepper adulteration, Czech Journal of Food Sciences. 19: pp. 235-239.

Vijayan, K.K. and Thampuran, R.V.A. (2000). Pharmacology, toxicology and clinical application of black pepper. In: Black Pepper (Piper nigrum L.). (Ravindran, P.N. Ed.), Amsterdam: Harwood Academic Publishers. pp. 455-466.

Yogesh, M.S. and Mokshapathy, S. (2013). Production and export performance of black pepper, International Journal of Humanities and Social Science Invention. 2: pp. 36-44. 